\title{
Sino-Egypt Relations in the context of BRI
}

\author{
Amr Adawi Ahmed Adawi \\ Ph.D. Scholar at School of International Relations and Public Affairs, \\ Shanghai International Studies University, \\ Shanghai China. \\ Amr531@gmail.com \\ Dr. Wang Lian He \\ Professor at School of International Relations and Public Affairs, \\ Shanghai International Studies University, \\ Shanghai China. \\ Wanglianhe_dc@163.com \\ Dr. Allauddin \\ Ph.D fellow at School of International Relations and Public Affairs, \\ Shanghai International Studies University, \\ Shanghai China. \\ allauddin_kakar@yahoo.com
}

\begin{abstract}
Sino-Egypt diplomatic relationships were established in May 1956. In year 2013, China launched the "Belt and Road" Initiative (BRI) and invited countries, especially those along the route to contribute in the framework of the project. The Egyptian president Sisi visited China in 2014, and the two nations agreed to promote their bilateral relationships to comprehensive strategic partnership. In year 20146, Egypt launched new strategy for national development "Egypt Vision 2030". Therefore, the two countries are cooperating according to these two planes. This paper analyzes Sino-Egypt relations in the context of BRI. When the Initiative was launched by China in 2013, Egypt is among the first countries to the join it. SinoEgyptian relations have significantly developed since the early 2010s. Based on solid foundation, China's president $X i$ Jinping and Al-Sissi sealed an "integral strategic
\end{abstract}


partnership" between the two nations in year 2014. This research paper provides an overview of this evolution and explores fields of cooperation between the two countries. The paper sheds light on cooperation in bilateral fields, especially in the framework of Belt \& Road Initiative launched by China. The paper explores how Egypt and China reinforce each other in their common search for economic development.

Key Words: Egypt, China, Belt and Road, Arab world, Africa, Investment, economic development.

\section{Introduction}

The Sino-Egypt bilateral relationships have evolved across stages since the historic meeting between President Nasser and Premier Zhaou Enlai in 1955, where the two leaders agreed to establish formal diplomatic ties which materialized in 1956. Egypt became the first Arab, African, and Middle Eastern country to establish an embassy in Beijing. Furthermore, Egypt supported the China's membership at the United Nations. Under the leadership of President Abd El Fattah El Sisi and President Xi jinxing the two countries have agreed to upgrade their bilateral relations, particularly after China's support to the will of the Egyptian nation after the $30^{\text {th }}$ June revolution, an act of support that is etched in the memory of Egyptian people and is cast with pride within. This support of China further strengthened the relations between the two countries. Since 2014, the Egyptian President has made six official visit to China and a historic visit of China's President Xi Jinxing to Egypt in 2016. Soon, this gave way to a mutual decision to further upgrade comprehensive strategic partnership during the visit of State Councilor and Minister of Foreign Affairs of China Wang Yi to Egypt in January 2020 (Badri, 2020).

The "Belt and Road" Initiative proposed by China in 2013 has received widespread recognition in Egypt and the Arab world. Meanwhile, the political transformation of Egypt has entered a new stage, with main objective to seek stability and promote development (Chaziza, 2016). With 
the completion of the new Suez Canal project in Egypt in 2014, and the launch of "Belt and Road" Initiative by China in 2013, there is now a framework of economic exchange benefits, a major actor in in promoting the role of bilateral industrial transfers between the two countries (Soliman \& Zhao, 2019).

Sino-Egyptian relationships are a strong example of a successful win-win partnership. As the sea route passes through Suez Canal to Europe, it enhance the significance of Egyptian position in "Belt and Road" Initiative (BRI). In the BRI, Egypt is become a focal point by providing promising opportunities for trade and investment for Chinese companies. Egypt has always taken interest in investing Chinese firms in projects ranging from, infrastructure development, power plants, renewable energy, and electric train projects. The Suez Canal Commercial Zone is proving to be a successful project. The success of the project is obvious from the fact that many investors the Egypt have expressed their willingness to contribute in the development of industrial zone (Morsy, 2019).

Egypt has joined the Chinese development Initiative in order to promote cross border communication, enhance commercial and investment cooperation, and bring home global cooperation in manufacturing capacity and equipment. Egypt has been experiencing trade deficit and decline in its foreign exchange reserves, and it also had to improve infrastructure, particularly the port and economic zone. The comprehensive strategic partnership between the two countries have provided impetus to economic development of Egypt with enhancement of political trust, promoting bilateral trade, and promoting smooth conduct of financial cooperation (Xiaohua, 2020).

China places great emphasis on promoting bilateral relationships between the two countries. The two countries have conducted exchanges at high level and are cooperating on matters of great significance. In order to jointly forge Egypt as a pillar nation along the BRI route, both countries are using infrastructure development and production capacity opportunities (Hoh, 2019). The noteworthy cooperation projects between the two countries are Industrial Zone investment by Chinese government, 
the Western Sahara project by China, and the Egyptian new capital city project. In addition to this, China is investing in Egyptian new capital city to build an electric train. Egypt is also expanding Chinese industrial investment, which also includes the construction of a textile industrial zone.

\section{Egypt's Cognition of China's "Belt and Road" Initiative}

The "Belt and Road" Initiative was welcomed by Egypt soon after its announcement by China and Egypt became the first country to join the project. In year 2014, Egypt officially announced to support the "Belt and Road" Initiative launched by China. The newly elected president of China, before his first official visit to China, stated that China's "Belt and Road Initiative was an opportunity for cooperation between China and Egypt, and Egypt was willing to participate in it actively"(Chen, 2018). Realizing the significance of the Initiative, the Egyptian government launched "China Affairs Section" led by Prime Minister. In words of former Prime Minister of Egypt , " The Belt and Road Initiative can unite China and the developing countries in Africa to achieve common development. " Egypt considers the Initiative significant for the country. The Egyptian ambassador to China stated that "The Belt and Road Strategic Initiative has brought opportunity to Egypt" (Chen, 2018).

The Initiative has also got close attention of the Egyptian media. The AlAhram newspaper's president asserted that, "The Belt and Road Initiative has raised the great symbolic value of the ancient Silk Road to strengthen economic cooperation, equality and mutual benefit on the basis of justice and peace, and the vision of the 21st-Century Maritime Silk Road made the Initiative truly international instead of being only limited to the countries along the ancient Silk Road" (Said, 2016).

The Egyptian scholars also view the investment of China crucial for Egypt. Salah Abu-Zeed argued that the Initiative was based on win-win cooperation and would play significant role in the development of Egypt. $\mathrm{He}$ added that, the Initiative would bring peace and stability, cooperation and integration. Thus, it reveals the positive perception of Egypt in regards to BRI, and its active response to the Chinese Initiative in Arab and 
African world (Zeed, 2017). Najar, a prominent Egyptian economist is of the opinion that: "Egypt and China have great potential for economic and trade cooperation. Egypt is blessed with excellent tourism resources and a large number of Chinese people choose to travel to Egypt every year; Egypt is rich in mineral and stone reserves, and Chinese enterprises can develop the resources on the basis of mutual benefit and reciprocity."

The stable and peaceful environment of Egypt attract more tourism and foreign investment, thus supporting the economy of the country. Egypt has prepared the national recovery plan in which China is playing a significant role. China and Egypt have great potential for investment cooperation. The Chinese development Initiative plays crucial role in promoting peace and stability, particularly in enhancing political and economic cooperation. With the positive growth of Egypt's macro-economy, the two countries have gradually strengthened cooperation in the political, economic and commercial spheres (Peng \& Zhang, 2019). Presently, the Egyptian government has signed a series of agreements with Chinese government in order to foster economic and trade relations between the two countries.

\section{China's Cognition of Egypt "Vision 2030"}

The "Vision 2030" is a development plan announced by Egyptian government in 2014. Soon it was launched by Egypt, China welcomed and announced to support Egyptian "Vision 2030" and synergize BRI project and Egyptian Vision 2030. In September 2017, during BRICS Xiamen Summit, China's president Xi Jinping during its meeting with Egyptian President Sisi argued that: "We need to synergize the development strategies and take advantage of the building of infrastructures and cooperation on capacity to make Egypt a supporting country along the Belt and Road" (Beijing Daily, 2017).

During the 8th China-Arab States Cooperation Forum meeting in Beijing in July 2018, Foreign minister of China announced that government of China was keen to foster cooperation between China's development strategy and that of Egypt's 'Vision 2030' and invited Egypt to contribute 
to the co-building of BRI project and to improve cooperation on capacitybuilding capabilities (China News, 2018).

In September 2018, President Sisi of Egypt attended the China-Africa Cooperation Forum Summit in Beijing and also held talks with President $\mathrm{Xi}$ Jinping of China. In the summit, the Chinese premier regarded Egypt as trustworthy and reliable partner, and express its willingness to synergize BRI and Egyptian Vision 2030, fostering the two countries' s pragmatic cooperation and strengthening their cooperation and development strategies (Xinhua News Agency, 2018).

In addition, in a joint interview with the Chinese media prior to the commencement of summit, China's ambassador to Egypt in his statement said that the central theme of the summit was bilateral cooperation and cobuilding of a stronger China-African common destiny community, and that the main objective was to integrate China's development Initiative with those of regional countries. China is positive about Egypt's 'Vision 2030' and claims that China and Egypt have significant opportunities for strategic cooperation. The Egyptian Vision 2030 aims at development and environmental protection, creating jobs and improving quality of labor, and promoting Egyptian economic and social development, thus leading towards a developed country that is good at creativity, emphasizing the livelihood of people and sustainable development (Dong, 2018).

\section{Sino-Egyptian Strategic Coordination}

China and Egypt have successfully maintained a firm and trustworthy relations in the last 60 years. Since the establishment of their diplomatic relationships, the two nations always stand by each other; cooperated, and supported each other's stance at global level. Relationships between the two countries have been progressing smoothly. Abd EI-Monem Fawzy, an expert in China-Africa relations at the Al--Gomhuria Center for Strategic Research asserted that: "Egypt and China enjoy distinguished relations that have been elevated in the last few years to the level of comprehensive strategic partnership" (Samir, 2019). 
Both countries are currently focusing socio-economic development and rejuvenation. China and Egypt are now more engaged in high-level official visits, providing firm support to the core interests of each other and constantly enriching the strategic partnership. The two nations have synergized their development plans, developing infrastructure and production capacity making Egypt a supportive country along the route of BRI project (John, 2020).

From the region's viewpoint, the Middle Eastern and African nations "look to the east," which keeps pace with China's rapid opening to the west. "As an important member of the Sino-Arab Cooperation Forum and the Sino-African Cooperation Forum, the status of Egyptian regional power helps to organize and foster contact and cooperation between China and these countries, so that the development of Sino-Egyptian ties encourages the trend of" near East and West (Chen, 2018).

Egypt applied for the membership of AIIB membership in March 2015. In the month of September of the same year, Egyptian president, on the invitation of Chinese government, attended the $70^{\text {th }}$ anniversary celebration of the victory of the Chinese People "War of Resistance" against Japanese aggression, and the world "Anti-Fascist War", and observed parade along with the representatives from other nations. Simultaneously, Egypt also sent its troops to participate in the march-past results of the parade (Soliman, 2019).

In December 2014, Egyptian president visited China where the two countries signed a joint declaration on the establishment of a comprehensive strategic partnership. China, the second largest economic power in the world and largest trading partner of Egypt, has become a significant focus of the "Looking East" diplomatic agenda of Egypt (Morsy, 2019).

Additionally, in January 2016, Chinese president visited Egypt, which was indeed the first official visit by a Chinese leader in twelve years. Leaders of the both countries agreed to implement five-year program of the Strengthening of the Comprehensive Strategic Partnership between the 


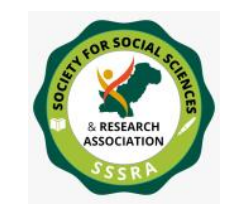

two countries (China Daily, 2016). The Memorandum of Understanding between the Government of the People's Republic of China and the Government of the Arab Republic of Egypt on the Joint Promotion of the Silk Road Economic Belt and the Maritime Silk Road of the 21st Century was also signed by the two countries, along with a number of documents relating to bilateral cooperation in the fields of electricity, infrastructure building, economics, trade and energy.

Moreover, the leaders also signed the second phase of the Sino-Egyptian trade cooperation, and Suez economic zone which is expected to bring together more 100 companies investing in the field of textiles and clothing, oil machinery, motorcycles and solar energy, with the potential to generate more than 10,000 jobs for Egypt (Xinhua Net, 2016). The visit led to further promoting of strategic partnerships between China and Egypt, and making together the BRI and Egyptian Vision. Thus, enhancing Chinese companies' foreign investment in Egypt.

In year 2017, the BRICS (Brazil, Russia, India, China, and Africa) summit was held in Xiamen, China. On the special invitation of Chinese government, the Egyptian president also attended the summit. In order to share their development experiences, the Summit offered an important communication forum for developing market countries and developed countries, thus assisting them to find their own development strategies to promote South-South cooperation. The two countries have successfully maintained coordination and cooperation on security, and regional and international issues (Today, 2020).

In addition, in July 2018, the $8^{\text {th }}$ ministerial conference of "Sino-Arab Cooperation Forum" was held in Beijing, foreign ministers of more than twenty Arab nations participated in the conference, including Egypt (Hu, 2019). The declaration of "Action on China-Arab States Belt and Road Cooperation" and numerous other cooperation documents were jointly released by China and the Arab side. The Egyptian foreign minister, while speaking at the China Institute of Contemporary International Relations, argued that aims Sino-Egyptian economic cooperation are infrastructure development in Egypt and other areas of Africa (Chen, 2018). 


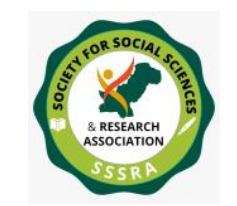

The Beijing summit of the China-Africa Cooperation Forum (FOCAC) was held at the beginning of September 2018 (Aiping, 2018). The Egyptian President attended the Summit and signed a series of agreements aimed at enhancing cooperation in numerous areas. As Egypt will become the next rotating president of the African Union, president is committed to make measures to foster cooperation between China and Africa. Egypt appreciated Chinese good holding of the summit, and supports China's equal position on the question of the Middle East (Sun, 2018).

\section{Facilities Connectivity}

After coming to the power, new Egyptian president has made great economic development efforts and believes that the construction of mega projects under "Vision 2030" would play crucial role in national development. These were perceived as the "highlights" of the development of Egypt in the coming decades. With major advantages in the fields of infrastructure, power, transport and oil, and in the near future, China will cooperate more closely with Egypt (Nadrian, 2018).

The Suez Canal which connects Asia, Europe and Africa and is considered as one of the World's most commonly used waterways. The new Egyptian government under president Sisi launched an extension project in August 2014 involving the excavation of a new $35 \mathrm{~km}$ long canal and the widening and deepening of an existing $37 \mathrm{~km}$ long canal. The new canal was successfully opened in August, 2015. Chinese firms including China Harbour Engineering Company Ltd. (CHEC) in the fields of electricity, rail and electronics, and so are investing the development of Suez Canal (Eric, 2016).

Moreover, the construction of Sohna Portto, south of the Suez Canal, was initiated by CHEC in August 2018. The development of Suez Canal economic zone will play significant role in promoting industrial cooperation between the two countries, and the next step is expected to further support the construction of the Sino-Egyptian Suez Canal Zone, to enable Chinese companies to join the Suez Canal Zone and to carry out the transfer and growth of industrial clusters. 
During the Chinese president visit to Egypt in year 2016, a set of documents were signed between the two countries including mega projects which amounts more than $\$ 10$ billion. China is playing crucial role in building the new capital city of Egypt. Additionally, the two countries have also signed the EPC agreements, comprising the construction of "National Convention Center", the parliament house building, the exhibition city, and the offices of the twelve ministries (Lin \& Ali, 2016).

Egypt is expected to become center of political and commercial activities with the completion of its new capital city project. It will significantly promote the development of "Suez Canal Economic Belt", "Red Sea Economic Belt", and successful implementation of Egypt's national development strategy. During the summit of "Forum on China-Africa Cooperation" held in Beijing in September 2018, the Chinese state Construction Engineering Corporation agreed an EPC with Egyptian ministry of investment and international corporation valuing $\$ 3.5$, and PEC contract for Suez refining and Petrochemical Plant valuing \$ 6.1 billion was also signed with the Egyptian Eastern Oil and Gas company ( Xinhua News Agency, 2016).

Presently, construction of the project under phase I which was signed in year 2016 is in progress, and once it is completed is successfully, the project is expected to be a symbolic one in the Sino-Egyptian relations in the context of the "Belt and Road". In terms of energy projects, first phase of the Egypt's state Grid $500 \mathrm{kV}$ transmission project was successfully completed and operationalized in October, 2016. The Egyptian government has expressed its contentment over the timely completion of the project. It was indeed the first project completed under Sino-Egypt cooperation in the framework of the "Belt and Road", with 760 million USD costs of investment. In terms of transport projects, the Light Rail Transit (LRT) electric train will be built between Cairo and Egypt's new capital which is expected to start in August, 2021 (Al-Youm). 
Table 1. Infrastructure Projects

\begin{tabular}{|c|c|c|c|}
\hline & Projects & Completed & To be completed \\
\hline \multirow{8}{*}{$\begin{array}{c}\text { Infrastructure } \\
\text { development } \\
\text { Projects }\end{array}$} & Construction & Extension of Suez & Suez Canal Zone \\
\hline & & Canal & The new Capital \\
\hline & & & $\begin{array}{l}\text { administrative center project } \\
\text { "The Suez Refining and }\end{array}$ \\
\hline & Energy & & Petrochemical Plant the \\
\hline & Projects & Egypt State Grid 500 & Ataqa Pumped-Storage \\
\hline & & $\mathrm{kV} \quad$ transmission & Power Station the Egyptian \\
\hline & & project & fired Project" \\
\hline & $\begin{array}{l}\text { Transport } \\
\text { Projects }\end{array}$ & $\begin{array}{l}\text { Roads \& Railways } \\
\text { Projects }\end{array}$ & $\begin{array}{l}\text { Transportation: Road \& } \\
\text { Railways under Suez Canal } \\
\text { extension project. } \\
\text { Electric train named "the } \\
\text { city of } 10 \text { days of Ramadan" } \\
\text { between Cairo and the new } \\
\text { Capital city. }\end{array}$ \\
\hline
\end{tabular}

Under Chinese investment, the transport projects are comprised of two electric-based train with designed speed of $120 \mathrm{~km} / \mathrm{h}$ with eleven route stations. The electrified train is designed with a total route of about $66 \mathrm{~km}$ with construction amount of $\$ 1.24$ billion. For residents along the railway, the project will provide great convenience. In 2018, power China and Egyptian electricity holding companies signed an agreement for the Ataqa Pumped-Storage Power Station and an EPC contract for the Egyptian 61100MW clean coal-fired project (Morsy, 2019). Table 1 provides brief details of the projects discussed.

\section{Sino-Egypt trade ties in the context of BRI}

With the Initiative of "Belt and Road, Sino-Egypt trade and investment, and bilateral trade is growing. Volume of the bilateral trade between the two countries exceeded \$ 10 billion yearly from 2013 to 2017, reaching to 
10.21 billion USD, 11.62 USD, 12.87 USD, 10.99 USD, and 10.87 USD (MEI Group, 2018).

Figure 1. Volume of Trade between China and Egypt from 2013-2017

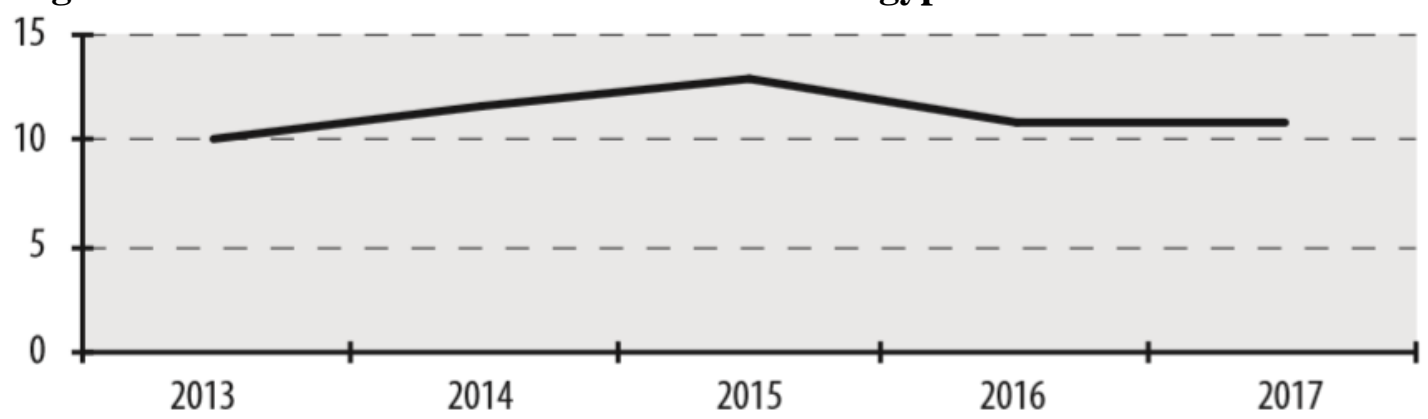

China is now the largest trading partner of Egypt, with mainly exporting mechanical and electrical products, vehicles and their accessories, steel and its products, plastic and plastic products and textiles etc. In terms of Egyptian imports, China receives crude oil, LPG (Liquefied Petroleum Gas), and agricultural products. Noticeably, Egypt increased its exports of agricultural products to China in 2017; the cost of fresh oranges reached to \$80 million from the month of January to September in 2017, with an enhanced annual growth rate of $208 \%$ (Ministry of Commerce, 2018).

China has increased its investment in Egypt steadily. Till year 2017, the direct and indirect investment by China in Egypt reached $\$ 7$ billion, and created more than 10000 job opportunities in Egypt. Currently, the ChinaEgyptian cooperation flagship project has attracted 68 settlement enterprises, with an investment of about $\$ 1$ billion; more than two thousand jobs have been created for local populace (Chen, 2018). For Chinese-funded enterprises, it has become a representative "bridgehead" in order to enter Egypt and Africa.

Chinese president, during his visit to Egypt in January 2016, launched the TEDA SUEZ (Phase II) construction project along with Egyptian president. Its size has been further broadened, adding more economic benefits to Egypt. In collaboration with other nations, it has become a blueprint for China's overseas industrial parks. 
The latest economic reports on Sino-Egyptian trade reveals that bilateral trade between the two countries with an increase of 27.7 percent reached to $\$ 13.8$ billion in year 2018. Economic and trade relations between the two countries have witnessed steady growth since "Belt and Road" Initiative. In the context of BRI, bilateral trade between the two countries reached a record level, with Egyptian exports to China reaching $\$ 1.8$ billion for the first time (Mena, 2019).

\section{Financial Cooperation}

China and Egypt have continuously strengthened financial cooperation. The two countries have achieve beneficial progress by signing memoranda, establishing financial institutions, providing investments and financial support. A three-year bilateral currency swap agreement was signed in December 2016 between the two countries' central banks which amounts $\$ 18$ billion. In addition, China's financial institutions are cooperating with Egypt, providing credit and loans in various fields with contract amount surpassing $\$ 5$ billion by the year 2018 (Zhai , 2018).

The China Development Bank issued a $\$ 1.4$ billion loan to Egypt's financial institutions in 2016, $\$ 900$ million was provided to Egypt's Central Bank, which was indeed the first larger level loan provided by Chinese development bank to a foreign country. In 2016, China surpassed United States in terms of oil imports (Meng, 2017). In order to enhance the use of RMB in global trade, and to recognize the important role of RMB, China focuses its comprehensive benefits such as investment and financing, dynamically encourages RMB pricing and settlement of oil.

\section{The Belt and Road and Suez Canal}

The Suez Canal Economic Zone is integrated with BRI which is expected to be a global logistic hub, making it one of the major development project in the world. According to the Planning Minister of Egypt "SC Zone's function is fully integrated with China's BRI to reinforce the international trade movement." (The Belt \& Road News, 2019). He added that "It has a pivotal role in increasing economic growth rates and creating more job 
opportunities in Egypt". The Suez Canal Economic Zone is also playing crucial role in promoting cultural exchange between Egypt and China.

China has the major contribution in numerous development projects undertaken in Egypt, particularly it is cooperating Egypt in the development of Suez Canal Economic Zone. With major contribution in Egyptian hard currency, along with tourism revenues, and foreign investment the 150-year old Suez Canal remained to be one of the Egyptian government main focus throughout history (Kamel, 2018).

The Egyptian president argued that the Suez Canal Corridor is significant zone for cooperation between the two countries, as the BRI continues to provide Egypt with momentum for economic development. China has launched the development project of Egyptian Suez canal economic zone, with several agreements on development with Chinese companies have been signed. "There are promising investment opportunities in the SC Zone and a growing desire of Chinese companies to invest here and be present at the Egyptian market," the Egyptian official revealed (Business Reporting Desk, 2019).

Presidents of the two countries jointly unveiled the name plate of the TEDA Cooperation Zone Expansion Area Project covering an area of six square kilometers during his 2016 state visit to Egypt. "Egypt is located at the border of Asia, Africa, and Europe and has established friendly relations with China. With the deepening of the BRI and the development plan of Egypt's Suez Canal Corridor, the establishment of a Chinese overseas economic and trade cooperation zone in Egypt will strengthen and deepen the capacity cooperation between the two countries, which has a profound significance," director of the TEDA cooperation zone (Xinhua, 2019).

"In November 1956, people from all walks of life in Beijing held a rally in the Tiananmen Square to support Egypt in safeguarding national sovereignty and to nationalize the Suez Canal," Chinese Ambassador to Egypt (Xinhua, 2019).

\section{Sino-Egypt Cultural ties}


China and Egypt are two ancient civilizations of the world. The two countries has always been engaged in promoting cultural exchange. Among the Arab world, Egypt is a country which has firm basis for cultural exchange with China, and it's highly accepts China's culture on its land. With "Belt and Road" Initiative, China and Egypt are also cooperating in people to people bond and cultural exchanges. The year 2016, which was $60^{\text {th }}$ anniversary of Sino-Egyptian diplomatic relationships, was also the year of Sino-Egyptian Cultural year (Chaziza, 2016)

The number of Chinese-speaking tour guides who introduce history and Egyptian culture to Chinese tourists in Egypt have reached to about 1000, which are deemed the folk ambassador of China-Egypt friendship. The number of tourists from China to Egypt has been growing with each passing year. In Egypt, China has established two Confucius Institutes and three Confucius Classrooms, with about 2000 registered students. There is also a rise in the number of foreign students on both sides. More than 1000 Egyptian students are currently studying in China, and over 2300 Chinese students are currently studying in Egypt. Presently, Egypt is one of the top rank countries in terms of hosting highest number of Chinese students (Kyle, 2017).

About 1000 direct flights operates between China and Egypt, which is playing crucial role in promoting people to people bond between the two countries. In Egypt, Chinese films and TV programs are also gaining popularity, helping Egyptians to better understand China's current development, conduct cultural exchanges and deepen bilateral cooperation (Chen, 2018).

\section{Conclusion}

To concluded, the paper discussed Sino-Egyptian relationships in the context of China's "Belt and Road" Initiative. It is obvious from the examined period of Sino-Egypt ties that the two countries have upgraded their relationship to a comprehensive strategic partnership. The nature of relations between Egypt and China were mostly based on a win-win 
cooperation and multiple trade, political and economic mutual benefits. The two countries have emphasized strategic cooperation relations among their prioritized aspects, and there has been considerable expansion and continuous development in numerous fields, e.g. trade, finance, infrastructure, transportation, technology etc. With the "Belt and Road" Initiative China is now more interested in Egypt. Egypt has become strategic element of China's "Belt and Road" Initiative. China launched the "Belt and Road" project in 2013 with aim to connect Eurasia via strategic trade route. Though the BRI mainly focuses on East Africa, China has integrated countries in Central and West Africa and Egypt; Egypt has become fourth largest country in terms of China's investment in Africa. The Chinese interests in Egypt have led to valuable revenue into the country.

For many key reasons, China is now interested in Egypt as a strategic partner. Firstly, the Suez Canal is a significant transport artery of the world and a key link in the 21st Century Maritime Silk Road. In this context, cooperation and investment in Egypt is becoming a crucial focus of China. Secondly, the increasing role of China contributes to rising Chinese role in the Mediterranean region. With the growing military and diplomatic cooperation between China and Egypt, this may lead to enhanced pressure on the EU countries. The Chairmanship of the African Union and influential role in the organization, Egypt has become crucial country for China in achieving its interest in the African continent. Finally, Egypt remains central to Chinese foreign policy objectives. 


\section{References}

Abu-Zeed (2017, May 12). The "Belt and Road" Initiative Is of Great Significance to the Arab World and the Middle East. People's Daily Online. http://news.sohu.com/20170512/n492761602.shtml.

Aiguo, S. (2017, May 22) Promote Sino-Egyptian Cooperation Based on the "Belt and Road". Study Times. https://www.fmprc.gov.cn/ce/ceegy/chn/zxxx/t1464406.htm.

Aiping, Z., \& Zhan, S. (2018). Origin, Achievements, and the Prospects of the Forum on China-Africa Cooperation. China Int'l Stud., 72,88.

Al-Youm, Al-M. (2020, October 18). Egypt to begin electric train trial operation in August 2021: Minister. Egypt Independent. https://www.egyptindependent.com/egypt-to-begin-electric-traintrial-operation-in-august-2021-minister/

Badri M. (2020). Egypt and China: Historical relationship into the future. Global Times. https://www.globaltimes.cn/content/1189854.shtml

Beijing Daily (2017). Xi Jinping Met with the President of Guinea, President of Egypt and Prime Minister of India Respectively. http://bjrb.bjd.com.cn/html/2017-09/06/content_173054.htm.

Business Reporting Desk. (2019). Chinese Companies pioneer development of Egypt's Suez Canal Region. Beltandroad News https://www.beltandroad.news/2019/10/09/chinese-companiespioneer-development-of-egypts-suez-canal-region/

Chaziza, M. (2016). Comprehensive Strategic Partnership: A new stage in China-Egypt relations. Meria Journal, 20(3).

Chaziza, M. (2016). Comprehensive Strategic Partnership: A new stage in China-Egypt Relations. Meria Journal, 20(3).

Chen J. (2018, July 10). Egyptian Foreign Minister Sameh Shukri: ChinaArab States Cooperation Forum Is an Excellent Communication 
Platform. News CYOL. http://news.cyol.com/yuanchuang/201807/10/content_17369655.htm.

Chen, J. (2018). Strategic Synergy between Egypt "Vision 2030" and China's "Belt and Road." Initiative. 11(5).

China Daily (2016). Chinese president arrives in Egypt for state visit. https://www.chinadaily.com.cn/world/2016xivisitmiddleeast/2016$\underline{01 / 21 / \text { content_23174025.htm }}$

China Economic Net (2016, 23 January). Let the "Belt and Road" Yield Positive Results in Egypt. News Sohu. http://news.sohu.com/20160123/n435594853.shtml?z_n951t.html.

China News. (2018, July 8) Talks between Wang Yi and Egyptian Foreign Minister Shukri: Welcome Egypt's Participation in the "Belt and Road. News Sina. http://news.sina.com.cn/o/2018-07-08/docihezpzwt6798588.shtml.

China State Construction Won the Order of Construction of the Egypt New Capital Valuing USD 2.7 Billion (2016, January 22). Xinhua News Agency, http://www.xinhuanet.com/201601/22/c_128654197.htm.

Construction of Industrial Parks Ensures Stable Development of the "Belt and Road" (2017, September 25). China-wl.cn, http://news.56888.net/2017925/4660199732.html.

Dong B (2018). Egypt, Find A Way Out. World Affairs, May 1, 2018. http://www.sohu.com/a/230031924_825951.

Eric, K. (2015). Egypt's Sisi Launches Nationalist New Suez Canal celebration. Reuters. https://www.reuters.com/article/us-egyptsuezcanal/egypts-sisi-launches-nationalist-new-suez-canalcelebration-idUSKCN0QB1LP20150806. 
Fast Read President Xi Jinping's Visit to Egypt (2016, January 23). ChinaNews. http://www.chinanews.com/ gn/2016/0123/7729187.shtml.

GK Today (2020). 9th BRICS Summit: Background; Highlights and Xiamen declaration. https://www.gktoday.in/gk/9th-brics-summitbackground-highlights-and-xiamen-declaration/.

Hazem, S. (2019). Sino-Egyptian Ties Flourishing: Cooperation in infrastructure and industrialization providing win-win development. China Africa http://www.chinafrica.cn/Homepage/201904/t20190425_80016599 $\underline{4 . h t m l}$

Hoh, A. (2019). China's Belt and Road Initiative in Central Asia and the Middle East. Digest of Middle East Studies, 28(2), 241-276.

Houlden, G., \& Zaamout, N. M. (2019). A New Great Power Engages with the Middle East: China's Middle East Balancing Approach.

Hu, J. (2019). R\&B Initiative Strengthens the Cooperation Between China and Arab Countries. China's Foreign Trade, (2),19.

John, C. (2020) Towering Ambitions: Egypt and China Building for the Future. Middle East Institute. https://www.mei.edu/publications/towering-ambitions-egypt-andchina-building-future

Kamel, M. S. (2018). China's Belt and Road Initiative: Implications for the Middle East. Cambridge Review of International Affairs, 31(1), 76-95.

Kyle, H. (2017) the Rhetoric of "Civilization" in Chinese-Egyptian Relations. Middle East Institute. https://www.mei.edu/publications/rhetoric-civilization-chineseegyptian-relations. 
Lin N. \& Ali. (2016). China's Xi promises 'billions' in investment during Egypt visit. Reuters. Business Insider. https://www.businessinsider.com/chinas-xi-promises-billions-foregypt-2016-1

Mena (2019). China's BRI boosts Egypt's development via massive infrastructure projects: Egypt Today. https://www.egypttoday.com/Article/1/68016/China-s-BRI-boostsEgypt-s-development-via-massive-infrastructure

MIE Group, (2018). Sino-Egypt Economic and Trade Cooperation Starts Accelerating. https://item.btime.com/m_98803a16fcc944ebb.

Ministry of Commerce (2017, December 28). Foreign Investment Cooperation Country (Region) Guide: Egypt People's Republic of China., https://www.yidaiyilu.gov.cn/zchj/zcfg/6648.htm.

Mohamed Soliman, M. A. M., \& Zhao, J. (2019). The Multiple Roles of Egypt in China's 'Belt and Road. Initiative. Asian Journal of Middle Eastern and Islamic Studies. 13(3), 428-444.

Mohamed Soliman, M. A. M., \& Zhao, J. (2019). The Multiple Roles of Egypt in China's 'Belt and Road.' Initiative. Asian Journal of Middle Eastern and Islamic Studies, 13(3), 428-444.

Morsy, A. F. I. (2019). The impact of the "Belt and Road initiative": in Egypt's economy and foreign policy (Doctoral dissertation).

Nadrian, T. A. (2018). Egypt in The Age of Modern Diplomacy: Exercises of Renewable Energy. Jurnal Sentris, 2(2), 79-90.

Qi, S. Z., Peng, H. R., \& Zhang, Y. J. (2019). Energy intensity convergence in Belt and Road Initiative (BRI) countries: What role does China-BRI trade play? Journal of Cleaner Production, 239, 118022 . 
Said A. (2016, July 29). The "Belt and Road" Initiative Evokes the Value of Justice and Peace. Global Times.http://opinion.huanqiu.com/1152/2016 07/9238175.html.

Xiao Hua, L. (2020). Capacity Building-Oriented Cooperation between China and BRI Countries. China Economist, 15(2), 20-29.

XINHUA (2019) Spotlight: China, Egypt join hands to write new chapter of Suez Canal development. Xinhua.net. http://www.xinhuanet.com/english/2019-11/18/c_138563688.htm

Xinhua News Agency (2018, September 2). Talks between Xi Jinping and Egyptian President Sisi. http://world.huanqiu.com/article/2018 09/12900390.html.

Zhai, F. (2018). China's Belt and Road Initiative: A Preliminary Quantitative Assessment. Journal of Asian Economics, 55, 84-92. 